\title{
Klasik Türk Şiirinde Tasavvufî Açıdan Tûr-i Sînâ
}

\begin{abstract}
Özet
Dağlar, yükseklik ve heybetleri ile inanan insanların gönül ve zihinlerinde ilahî azamet ve kudreti çağrıştıran, dinî-tasavvufî hisleri coşturan en önemli yeryüzü şekillerindendir. Bu çerçevede hemen hemen her din, dağlara özel bir anlam yüklemiş ve bazı dağları kutsal kabul etmiştir. Hz. Musa’nın Allah ile konuştuğu ve ilahî tecelliye mazhar olduğu yer olması münasebetiyle Tûr-i Sînâ bu dağlar içerisinde önemli bir yere sahiptir. Peygamber kıssaları ve bu kıssalarda yer alan unsurlardan etraflı bir şekilde faydalanan klasik Türk şiiri, Tûr-i Sînâ’ya tecelliye mazhar olma bakımından özel bir önem atfetmiş ve bu eksende onu özellikle aşk, gönül, vücut, insan-ı kâmil, âşık, tevazu, mahviyet, şevk, vecd, cezbe ve istiğrak gibi bazı tasavvufî kavram ve hâllerin anlatımında temel figürlerden biri olarak kullanmıştır. Bu çalışma, Tûr-i Sînâ'nın klasik Türk şiirinin tasavvufî muhteva esasına dayalı olarak anlam dünyası içerisindeki yeri, sembolik derinlikleri, ifade ettiği anlamlar, ilişkili olduğu kavramlar ve bu kavramların anlatımında yer alış tarzları incelenerek değerlendirilmesine yöneliktir.
\end{abstract}

Abdullah EREN1

Anahtar kelimeler: Tûr-ı Sînâ, klasik Türk şiiri, tasavvuf, tecelli, aşk.

\section{Mount Sinai from Mystical Aspect in The Classical Turkish Poetry}

\begin{abstract}
The mountains are one of the most important structures of the earth that excite religious-mystical feelings, evoke the divine power and might in the hearts and minds of religious person. In this frame, almost every religions give a special meaning to the mountains and accept some of the mountains as sacred. Mount Sinai has an important place in these mountains. Because, Prophet Moses talked to God here and saw holy light on this mountain. The classical Turkish poetry contains parables of the prophets and elements of this parables comprehensively, attributes special importance to Mount Sinai in terms of being manifestation place, and this axes uses it as one of the basic figures in the narration of some mystical concepts and events such as especially love, heart, body, murshid, lover, humility, enthusiasm, rapture and mystical contemplation. This study aims to examine and evaluate the Mount Sinai with its symbolic depths, meanings, related concepts and the way of taking place in the expressions of these concepts as based on meaning world of mystical contents in the classical Turkish poetry.
\end{abstract}

Key words: Mount Sinai, classical Turkish poetry, sufism, manifestation, love.

\section{Giriş}

Yerkabuğunun hareketleri, volkanik yığılmalar ve aşınmalara bağlı olarak ortaya çıkan yükseltiler hüviyetinde olan dağlar; coğrafî yapıları, iklimleri ve dolayısıyla ekosistemi, insan ve toplum hayatını etkileyen ve belirleyen yeryüzü şekillerinden olmanın yanında kültür ve medeniyetlerin hafızasında derin izleri olan yapılardır.

Prof. Dr., Ordu Üniversitesi, Fen Edebiyat Fakültesi, Türk Dili ve Edebiyatı Bölümü, abdullaheren@odu.edu.tr [Makale kayıt tarihi: 5.7.2018-kabul tarihi: 15.8.2018] 
Dağlar, yükseklik, büyüklük, aşılmaktaki zorluk, bilinmezlik ve tehlikeleri ile heyecan, merak, saygı ve korku; tatlı su, otlak, avlak, korunma ve barınak sağlamaları gibi yönlerden sevgi, ümit, güven ve minnet hislerini uyandırırlar. Bu özellikler ve bunlara bağlı hisler toplumsal hayat tarzı, düşünce yapısı ve dolayısıyla maddi ve manevi kültürün şekillenmesinde çeşitli roller üstlenir.

Dağların özellikle yükseklik, büyüklük, ulaşımdaki zorluk ve bilinmezlik yönüyle insan muhayyilesinde fizik ötesi anlamlandırmalara müsait yapılar olmaları onlara kutsallık atfedilmesi sonucunu doğurur ve çeşitli kültür ve inançlarda bazı dağlar bu yönleri ile ön plana çıkar.

"Kutsal dağ kültüne hemen hemen bütün ülke ve kavimlerde rastlamak mümkündür" (Harman 1993: VIII/400). Japonların Fuji-Yama, Çinlilerin K'ouen-louen, Hintlilerin Kalios ve Himalaya, Fenikelilerin Lübnan dağları, Yunanlıların Olimpos, Perslerin Elburuz, Türklerin Altay ve Tanrı dağları kutsal kabul edilen dağlardandır. "Dinlerde mekânın kutsallığına paralel olarak dağların ayrı bir önemi vardır. Dağların kutsal oluşu ve onlara karşı tazimde bulunulması, Tanrı'ya en yakın yerler olarak kabul edilmeleri, daha gelişmiş dinlerde ise Tanrı'nın yüceliğini ve aşkınlığını sembolize etmelerinden ileri gelmektedir. Dağların bulunmadığı yerlerde insanlar, yüce varlığa yakınlaşma ihtiyaçlarını çeşitli kuleler inşa ederek karşılamaya çalışmışlardır” (Harman 1993: VIII/400).

Semavi dinlerde ise peygamberlerin hayatlarında önemli yer tutan dağlar kutsal kabul edilmiştir. Yahudilikte Sînâ ve Siyon dağı, Hıristiyanlıkta Zeytin dağı, Müslümanlıkta Arafat, Hira, Sevr ve Ebu Kubeys dağları bu dağlar içerisinde ilk akla gelenlerdir. " "İslâm'da bazı dağların çeşitli sebeplerle ayrı bir tazime konu oluşu, sadece oralarda cereyan eden dinî olaylarla ilgili olup hiçbir zaman dağlara tanrısal bir hüviyet atfedilmemiş ve buralar tapınma konusu yapılmamıştır” (Harman 1993: VIII/401).

Kur'an-ı Kerîm'de dağlarla ilgili olarak onların nasıl dikildiğinden ibret alınması gerektiği (Gâşiye 88/19), yeryüzüne birer kazık yapıldığı (Nebe 78/7), yeryüzünün sağlamlaştırılması ve sarsılmaması için sağlam bir şekilde yerleştirildiği (Nahl 16/16, Enbiyâ 21/31, Nâzi’ât 79/32), üzerinde ve içinde barınakların ve madenlerin yaratıldığı (Nahl 16/81, Fâtır 35/27), Allâh’ı tespih ettiği (Sâd 38/18, Sebe 34/10, Enbiyâ 21/79); kiyamet gününde yürütüleceği (Kehf 18/47, Tûr 52/10), yürütülüp serap hâline geleceği (Nebe 78/20), kaldırılıp birbirine çarptırılacağı (Hâkka 69/15), parça parça olup dağılacağı (Fecr 89/21), sarsılacağı ve akıp giden kum yığını olacağı (Müzzemmil 73/14), parça parça dağıtılıp ufalanarak toz olacağı ve savrulacağı (Vâkı'a 56/7, Mürselât 77/10, Tâ-Hâ 20/105) ve atılmış renkli yünler gibi olacağı (Me’âric 70/9, Kâri’a 101/5) gibi konulardan bahsedilmiştir.

İlâhî emanetin ve Kur'an'ın haşmet ve azametinin anlatıldığı iki ayette ise dağların Allah tarafından kendisine teklif edilen emaneti yüklenmek istemediği ve bundan çekindiği, fakat onu insanın yüklendiği (Ahzâb 33/72); Kur'an bir dağa indirilmiş olsaydı, o dağın Allah korkusundan başını eğip parça parça olacağı (Haşr 59/21) ifade edilir.

Kur'an-ı Kerîm'de dağlar genel anlamda “cebel” ve "cibâl” kelimeleri ile karşılanmıştır. Özel isim olarak zikredilen dağlar tespit edebildiğimiz kadarıyla; Arafat, Cudi ve Tûr'dur. Arafat, hac ibadetiyle ilgili olarak zikredilir (Bakara 2/198). Cudi, Hz. Nuh'un gemisinin tufandan sonra üzerine oturduğu dağdır (Hûd 11/44). Özel olarak en çok konu edilen dağ, Tûr'dur.

\footnotetext{
2 Dağların eski kültürlerde ve semavi dinleredeki yeri hakkında geniş bilgi için bk. Hikmet Tanyu, Dinler Tarihi Araştırmaları, Ankara Üniversitesi İlâhiyat Fakültesi Yayınları, Ankara 1973. 
“Tûr, Süryanice 'dağ' demektir. Veya 'icadın zirvesinden maddenin çukuruna veya gayb âleminden şehâdet âlemine tayeran eden' demektir” (Kâdı Beydâvî 2011: 4/273). Yaygın görüşe göre Tûr ismi tek başına Tûr-i Sînâ'yl ${ }^{3}$ karşılamaktadır. Tûr Sûresi onun ismin taşımaktadır. Bu sûrenin birinci, Tîn Sûresi'nin ikinci ayetinde ona yemin vardır. Bir ayette, üzerinde yetişen hem yağ hem katık veren ağaçla birlikte zikredilmiştir (Mü’minûn 23/20). En yaygın şekilde ise Hz. Musa ile ilgili kıssalarda söz konusu edilmiştir. Hz. Musa burada Allah ile konuşarak vahiy almış ve ilahi tecelliye mazhar olmuştur.

Tûr'un ilgili kıssalar içerisinde yer aldığı ayetlerin bazıları -bu çalışmamızla doğrudan ilgili olanlarmealen şöyledir: "Hani bir ateş görmüştü de ailesine, 'Siz burada kalın, ben bir ateş gördüm (oraya gidiyorum). Umarım ondan size bir kor ateş getiririm, yahut ateşin başında, yol gösterecek birini bulurum' demişti. Ateşin yanına varınca, ona şöyle seslenildi: 'Ey Mûsâ!' 'Şüphe yok ki, ben senin Rabbinim. Hemen ayakkabılarını çıkar. Çünkü sen mukaddes vadi Tuvâ'dasın.' " (Tâ-Hâ 20/10-12). "Mûsâ, ateşin yanına gelince o mübarek yerdeki vadinin sağ tarafındaki ağaçtan şöyle seslenildi: 'Ey Mûsâ! Şüphesiz ben, evet, ben âlemlerin Rabbi olan Allah'ım.' " (Kasas 28/30). "Mûsa, belirlediğimiz yere (Tûr'a) gelip Rabbi de ona konuşunca, 'Rabbim! Bana (kendini) göster, sana bakayım' dedi. Allah da, 'Beni (dünyada) katiyen göremezsin. Fakat (şu) dağa bak, eğer o yerinde durursa sen de beni görebilirsin.' dedi. Rabbi dağa tecelli edince onu darmadağın ediverdi. Mûsâ da baygın düştü. Ayılınca, 'Seni eksikliklerden uzak tutarım Allah'ım! Sana tövbe ettim. Ben inananların ilkiyim' dedi." (A'râf 7/143).

Tasavvufî anlayışa göre Tûr-i Sînâ ile ilgili olarak ortaya konulan bazı anlamlandırmalar şöyledir: Abdulkerim Cîlî/Ceylî, Tûr'un mana bakımından bir yönünün insanı, insan nefsini karşıladığını ifade eder. Tecelli karşısında dağın parçalanmasını Hz. Musa'nın nefsinin fena bulması, Hz. Musa'nın bayılmasını ise kendi varlı̆̆ından geçip yok olarak Hazret-i Hak ile var olması olarak yorumlar. Tûr'un ayrıca nefsin bâtınî yönü, insanda bulunan ilâhî hakikat olduğunu söyler (Abdulkerim Ceylî 2018: 413, 414). İmâm-ı Gazâlî onu, kalplere marifeti ve keşif yoluyla görülebilecek güzellikleri aktaran varlıkların bir misali olarak anlamlandırır (İmam Gazâlî 1994: 46). İsmail Hakkı Bursevî, insan vücudunun Tûr'a benzediğini, özellikle Allah dostlarının sebat ve temkinleri ile dağ hükmünde olduğunu belirtir (İsmail Hakkı Bursevî [yz.]: 9b). Kuşeyrî, tevazu bahsini açıklarken Fudayl b. İyâzdan şu sözü nakleder: "Hak Sübhânehu ve Taâlâ dağlara şöyle vahyetti: 'İçinizden birisi üzerinde Peygamberimle konuşacağım.' Bunun üzerine dağların hepsi baş kaldırdı, boyunlarını uzattı, sadece Tûr-i Sînâ boyun eğdi, tevâzu gösterdi. Gösterdiği tevâzu sebebiyle Allah Taâlâ Peygamberi Mûsâ (a.s.) ile bu dağ üzerinde konuştu" (Abdulkerim Kuşeyrî 2003: 235). Mevlânâ Celâleddin Rûmî, Allah dostlarının vücut ve gönüllerinin kıymet ve yüceliğini anlatırken Tûr'dan şöyle bahseder: "Erlerin bedenleri, mükemmel kudretten tarif edilemez nura dayanma gücü kazanmıştır. Tûr’un kendisine bir zerre dayanamadığı nura Allah bir camdan yer yapar. Kandil yeri ve cam, ışık yeri olur; onun ışı̆̆ı̆la Kaf ve Tûr parçalanır. Bedenlerini kandil yeri, gönüllerini cam bil; bu kandil Arş’a ve feleklere ışık salmıştır. Onların ışıkları bu ışığa hayran olmuştur; ylldız gibi bu kuşluktan yok olmuştur” (Mevlânâ 2017: 838).

Tûr-i Sînâ, klasik Türk şiirinde genel itibarıyla ilgili Kur'an ayetleri ile iman edenlerin ve Allah dostlarının yüksek kıymet ve derecelerini vurgulayan "Ben göklere ve yere sığmam, fakat mü’min kulumun kalbine sığarım” (El-Aclûnî 2009: II/175) ve "...Ben kulumu sevince işiten kulağı, gören gözü, tutan eli, yürüyen ayağı olurum...” (Buhârî, Rikâk 38) mealindeki hadisler başta olmak üzere bazı hadisler ekseninde tasavvufî bakış açısına dayalı olarak tecelli, insan-ı kâmil ve Allah âşı̆̆ı ile ilgili

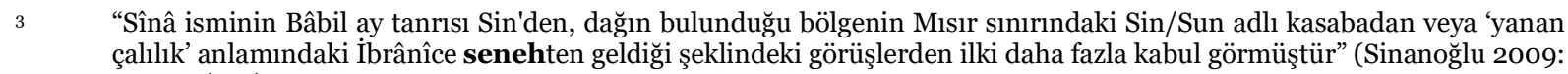
X̧alılı' anlamın/221). 
konuların anlatımında yer alır. Bu konular hâricinde yer yer sevgili, âşık, memduh ve şiir sanatı gibi konularda da genellikle bir benzetme unsuru olarak kullanılır. ${ }^{4}$

\section{Klasik Türk Şiirinin Tasavvufí Anlam Dünyası İçerisinde Tûr-i Sînâ}

Tûr-i Sînâ'nın klasik Türk şiirinde tasavvufi açıdan ele alınışı tecelli kavramı esasına dayalıdır ve tecellinin kâinat ve insandaki yansımaları, tecelliye ulaşma yolları ve ulaşıldığı takdirde ortaya çıkan hâllerin anlatımı şeklindedir. Bu anlatımlarda Tûr-i Sînâ, genellikle benzetme ve kıyaslamamalar içerisinde bir timsal olarak bulunur. İnsan-ı kâmil ve âşılar ile bunların gönül ve vücutları ya ona benzetilir ya da onunla kıyaslanır. Tecelliye bağlı olarak ortaya çıkan hâller ise onun sarsılıp, parçalanması örnekliğinde dile getirilir. Konu ile ilgili anlatımları 'tecelli', 'insan-ı kâmil', içerisinde âşık, onun gönül ve vücudu ile tevazu, fena, mahviyet, vecd, cezbe ve istiğrak gibi yaşadığı hâlleri barındıran 'aşk âlemi' olmak üzere üç ana başlıkta değerlendirmek mümkündür:

\section{Tecelli}

Tecelli, klasik Türk şiirinde Tûr-i Sînâ eşliğinde ele alınırken genellikle nur kavramı ile birlikte zikredilir ve Hakk'ın nurunun çeşitli derece ve mahiyetlerde bir şeye isabet veya sirayet etmesi, yansıması ve görünür-hissedilir hâlde bulunması şeklinde anlamlandırılır. Tecelli, Allah'ın kendisinin görünmesi veya yansıması demek değildir. Allah, gözlerin gördüğü, akılların hayal ettiği her şeyden münezzehtir. Böylece gerek Tûr'da, gerekse başka şeyde görünen tecelliler O’nun zatından ve zatının güzelliğinden büsbütün uzak olur. Nâ’ilî, bu hususu bir beyitte işaret yoluyla şöyle ifade eder:

Mûsî gibi hayrân-ı temaşası olurduk

Hüsnün şecer-i Tûr-ı tecellâda bulunsa

Nâ’ilî (G. 307-3)

Tecellinin genel ve özel olmak üzere başlıca iki çeşidi vardır. Genel tecelli bütün kâinata yansıyan, özel tecelli ise Allah'ın seçtiği hidayete ermiş kimselere has olan tecellidir.

Bütün cihan tecelli nurlarına mazhardır. Özellikle bahar mevsiminde bu durum daha da belirgin hâle gelir. Fakat bunu herkes görüp idrak edemez. O nurdan nasibi olmayan kimsenin gözüne Tûr'daki ağaçtan mil yapılıp sürme çekilse fayda etmez. Onu görüp anlayabilmek için can gözü açık bir âşık olmak gerekir. Münacat ehli, yani Hakk’ı gönülden isteyen âşık için her ağaç bir Tûr Dağı, ondaki her bir çiçek tecelli nurudur:

Hep cümle cihân mazhar-ı envâr-ı tecellî

Cân gözin açup 'âşık-ı dîdâr olabilsek

Nev'î (G. 258-2)

Nâ-kâbil-i müşâhede bî-behre nûrdan

Ger mîl-i sürme olsa ana nahl-i Tûr'dan

Kâtib-zâde Sâkıb (G. 457-1)

Her şecer bir Tûr tağıdur münâcât ehline

Her şükûfe anda envâr-ı tecellâdur begüm

Yahyâ Bey (G. 267-6)

\footnotetext{
4 Tûr'un klasik Türk şiirinde çeşitli konular içerisindeki kullanımı için bk. İnce, Adnan (1999). Dîvân Şüirinde İslâm Dîni Dışındaki Diğer Dinlerle İlgili Mefhumlar. Yayımlanmamış Doktora Tezi,: Trakya Üniversitesi Sosyal Bilimler Enstitüsü, Edirne; İnce, Adnan (2016). "Dîvân Şiirinde Hz. Musa" Tarih Kültür ve Sanat Araştırmalar Dergisi. 5/1. ss.64-74. 
Özel tecelli ile ilgili anlatımlar Hz. Muhammed, Hz. Musa; Tûr Dağı, gönül ehli, insan-ı kâmil ve âşıklar etrafında yoğunlaşır. Bu tecelli Allah tarafından, O’nun seçtiği kimselere mahsus kılınmıştır. Ona akıl yolunu tutan felsefecilerin erişmesi mümkün değildir:

$$
\begin{aligned}
& \text { Hak tecellî eyledi Mûsâ için } \\
& \text { Ne Aristalis ü Bû-Sîna için } \\
& \text { Ey gönül şol hûr-1 meh-sîma için } \\
& \text { Secde kıl hem şol kad-i bâlâ için }
\end{aligned}
$$

Nesîmî (Tuyug-246)

Tecelliye mazhar olmanın dereceleri vardır. En has tecelliye, Hz. Muhammed Miraç’ta ermiştir ve o, Hz. Musa'nın Tûr'da karşılaştığından farklıdır. Ahmedî, bu tecellinin mahiyeti ve farklı oluşunun sebeplerini bir kaside ve Mevlid'inde özetle şöyle anlatır: Allah'a nefis ve her ne kadar yüksek kıymet ve dereceye sahip olsa da ruh hazzı ile erişilemez. Bunlar, bu yolda iki büyük perdedir. Hz. Musa'da nefsani haz bulunmamakla birlikte, ruh hazzından eser vardır ve bu dahi perde olduğu için o, tecelliye ancak kelam ile ermiştir. Hz. Muhammed, ruh hazzı perdesini dahi aştı̆̆ından Allah'ın zat tecellisine mazhar olmuştur (Ahmedî, K. 57, 5-8; Mevlid 88-93). Âhî ise bu tecellileri celal ve cemal bakımından ele alır. Hz. Musa'nın celal, Hz. Muhammed’in ise cemal tecellisine mazhar olduğunu söyler:

Nâr-1 Mûsî'dür celâlün şemmesinden bir eser

Nûr-1 Ahmed'dür cemâlün pertevinden bir kabes Âhî (K. 1-4)

Tûr'daki tecelli, özel tecellinin küçük bir tezahürüdür. Böyle olmakla birlikte yine de dayanılacak hâlde değildir. Zira bu tezahürle, Tûr sarhoş olup kendinden geçmiş ve bu hâlde âdeta sema etmiş, Hz. Musa da baygın düşmüştür:

Döymez Kelîm şa'şa'a-i câm-ı vasluna

Bir lem'ası tokunmagile Tûr mest olur Şeyhülislam Yahyâ (G. 77-4)

Dâglar tâkat getürmez mest-i ser-gerdân olur

Şu'le-i nûr-ı tecellî ile Tûr eyler semâ‘

Nakşî (G. 126-2)

Bu tecelli en sağlam bakışa, bakış açısına sahip kimselerin ve onların gözlerinin dahi takat getirebileceği bir şey değildir. Onun ufak bir parıltısı akıl ve şuuru mahveder. Bu yüzden o vadideki sırlara aklın ermesi mümkün olmaz. Ona ancak gönüller erebilir. Hakk’’n nuru her gönle bir yönden tecelli eder. Fakat ancak irfan sırlarına mahrem olan arifler bunu müşahede ve idrak edip feraha ermiştir:

Erbâb-ı nazar tâb-ı cemâle döyemezler

Tâkat-şiken-i bâsıradur Tûr-ı tecellî

Beyânî (G. 818-2)

'Ukûl irmez o vâdîlerdeki esrâra hâmûş ol

Tecellî reşhası 'akl u şu'ûrı mahv ider her ân

Mehmed Sidkî (164-29)

Her dile bir vech ile kılmış tecellâ nûr-ı Hak

Mahrem-i 'irfan olan tuymış tesellâ semtini

Nev'î (G. 498-4)

Bir kimsenin Hakk’n tecellilerine erebilmesi için çeşitli şartlar vardır. Bunun için insan, Hz. Musa gibi Allah'ı görmeye, O’na kavuşmaya talip olmalı; gönlünü ve dolayısıyla bütün varlığını masivadan yani Allah'tan başka olan şeylerden temizlemelidir. Gönlünü masiva kırıntılarından temizleyen kişi Tûr gibi tecelliye erer: 
Kelîmvâr meger tâlib-i likâ olasın

Tecelliyât-ı Hak’a cismi Tûr idem dir isen Süheylî (G. 189-2)

Sâf olmayınca su gibi âyîne-i vücûd

Sanma ki ‘aks-i nûr-ı tecellâ ide zuhur

Yahyâ Bey (G. 129-4)

Derûnı pâk idüp gerd-i kederden Tûr-ı Mûsâveş

Tecellîgâh-ı nûr-ı zât-ı pâk-i kibriyâ olduk Süheylî (G. 161-3)

Bu yolda bir diğer şart, nefsin hayvani vasıflardan arındırılmasıdır. Gönlün melekler gibi tecelli nuruna erebilmesi için bu vasıfların ortadan kalkması gerekir:

Tecellî nûrına gönlün melek bigi irmek isderse

Gerek kim mahv ola senden kamu evsâf-ı hayvânî Ahmedî (K. 71-32)

Nefis benlik ve varlık davası güttüğünden dolayı firavun gibidir. Bu firavun, kahır Nilinde boğulmadıkça Hakk'ın cemal tecellilerini istemek olmaz. İnsan, tecelli nuruna ancak üstün bir gayret gösterip benliğini yok edebilirse kavuşabilir. Çünkü benlik ve buna bağlı varlık iddiası kibirdir. Kibir sahibi tevazu ve mahviyetten uzak olduğu için maneviyatı algılayamaz ve Hakk'a niyaz derecesine ulaşamaz. Niyaz Tûr'unda Hak ile kelâm edebilmek için varlık-benlik pamuğunu can kulağından çıkarmak gerekir:

Eger Fir'avn-ı nefsi Nîl-i kahre gark eylersen

Tecellâ-yi cemâl-i Hakkı Mûsî-veș temennâ kıl Zâtî (G. 817-3)

Anlayan mahv-ı enâniyyetde Mûsâ semtini

Bildi nâr-ı gayret ü nûr-ı tecellâ semtini

Nev'î (G. 498-1)

Ten penbesini cân kulağından çıkarmayan

Tûr-ı niyazda ide mi Hakk ile kelâm

Yahyâ Bey (Trc. B. 4/I-4)

\section{2. İnsan-1 Kâmil}

İnsan-ı kâmilin gönlü masiva kaydından arınmış, nefsinin hayvani yönleri ortadan kalkmıştır. O, daima Hakk'a münacat hâlindedir, gönlü tecelli nuru ile dolmuş ve böylece bütün varlığıyla Tûr hâline gelmiştir:

Mûsâ benim kim Hakk ile dâ’im münâcât eylerim

Gönlüm tecellî nûrudur anun için Tûr olmuşum Nesîmî (G. 248-3)

Kendisi böyle olmakla birlikte, Hakk'a yöneldiği yer de âdeta Tûr olur. Aşk ile coşar, nuru arşa çıar. Onun gören Tûr'a ihtiyaç duymaz. Ayak bastığı toprağın her bir zerresi tecelli Tûr'udur. Duası makbuldür. Ona yönelen, eli boş dönmez:

Hazret-i Mûsâ gibi cây-ı niyâzı Tûr olur

'Işk ile pür-şevk olur kandîl-i 'arşa nûr olur

Yahyâ Bey (Muaşşer 13/II-4)

Pey-rev-i pîr-i fenâ oldum ki hâk-i pâyinün

Tûr-ı ma'nâ-yı tecellîgâhdur her zerresi

Nehcî (G. 394-3)

Her gelen dest-i du'âmuzdan eli boş gitmez

Pîr-i ashâb-ı safâ Tûr-ı temennâyuz biz

Yahyâ Bey (G. 151-2) 


\section{Aşk Âlemi}

\subsection{Așk-Muhabbet}

Aşk, aşağılık dünya hırsının karanlıklarına boğulmuş nefsine ardını dönüp hidayet nuruyla ruh ve gönül âlemine yükselen insanın ulaştığı manevi iklimin en güzide meyvesi olan didar tecellisinin elde edildiği bir zirve olmakla Tûr Dağı'na benzer:

Tûr-1 '1ş̧ka kılmadun nûr-ı hidâyetle 'urûc

Şâm-1 gamda cilve-i dîdâr umarsin ey gönül $\quad$ Nev'î (G. 278-2)

Varlık esaretinden kurtularak hürriyete kavuşan âşıkların Hakk'a münacat yeri aşk Tûr'udur. Onu Hz. Musa’nın çıktığı Tûr ile kıyaslamamak gerekir. Çünkü ondaki tecelli nurları çok daha can yakıcıdır:

Hum-1 meyden götüri 'âlemi seyrân idelüm

Tûr-1 'sşka çıkalum yine münâcât idelüm

Avnî (G. 53-2)

Mahabbet kûh-sârın Tûr-1 Mûsầya klyâs itme

Bu kûh-sârun 'aceb cân-sûz olur nûr-ı tecellâsı

Azmizâde Hâletî (G. 823-3)

Muhabbet Tûr'undaki ateş bir ağaca veya dağa değil gönle sirayet etmiş, gönül ise tutuşmuş olduğu o ateşin bir meşalesi olmuştur. Muhabbetin tesiriyle 'sîne'de açlan yaralardan bu meşalenin ışıltıları görünmektedir:

Gönül rûşen-çerâg-1 şu'le-i Tûr-1 mahabbetdür

Şikâf-1 sîneden zâhir olan nûr-1 mahabbetdür

Mezâkî (G. 131-1)

\section{Âşık}

Âşıklar aşk Tûr'una, Hz. Musa Tûr Dağı'na çıkmadan ve orada Allah ile kelam etmeden çok daha önceleri Hakk'ın hitabına ve tecellilerine mazhar oldukları Elest Meclisi’nde çıkmışlardır. Onların gönlü daha Tûr Dağı'nda Hz. Musa’ya “beni göremezsin” cevabı verilmemişken Hakk’ın cemal nurunun tecellisinin Tûr'u olmuştur:

Ben Tûr-1 'ş̧ka çıkmış-ıdum hâsıl-ı kelâm

Mûsî Kelîm ü dahı kelâm olmadın henûz

Vusûlî (G. 69-5)

Bulmadın Mûsî hitâb-1 “len terânî”den cevâb

Pertev-i hüsnün tecellîsine gönlüm Tûr idi Hamdullah Hamdî (G. 164-3)

Âşıkların aşkı ve tecellilere mazhariyeti dünyaya gelmekle kesintiye uğramaz. Allah onlara her yeri Tûr eder. Onlar böylece içlerinde bulundukları aşk âleminde her yeri bir tecelli dağı olarak görürler:

Lâyık-ı nûr-ı tecellâya ne lâzım kûy-ı yâr

Hak Ta'âlâ ehl-i 'sşka her makamı Tûr ider

Yahyâ Bey (G. 79-3)

Kûy-i 'ışkun bana bir kûh-i tecellî görinür

Kalbüme ‘îd-i visâlünle tesellî görinür

Nakşî (G. 50-1) 
Âşık için aşk, bir tecelli ateşi mahiyetindedir. Bu ateş ona, fenâya ulaşma yolundaki her bir vesileyi, zahirde tehlikeli de olsa, Tûr'da tecelliye mazhar olan ağaç gibi gösterir. Muhabbetin Allah vergisi şevki de, belânın karanlık gecesindeki âşılara âdeta Tûr'daki ağaç olur:
Aşk âteş-i tecellî-i Mansûrdur bana
Her çûb-ı dâr bir Şecer-i Tûrdur bana
Şeyh Gâlib (G. 1-1)
Olur şeb-i târik-i belâda şecer-i Tûr
Erbâb-ı gama şevk-ı hudâ-dâd-ı mahabbet
Nâ’ilî (G. 27-4)

\subsubsection{Gönül}

Âşıklar, Tûr tabiatlıdır. Hakk'ın gönül kulağına gelen hitabı ile aşk Tûr'u olmuşlardır ve her yana aşk kokusu yayarlar. Gönülleri aşk şimşekleri ile aydınlanmış, tecelli nurlarıyla Tûr'a dönmüşs, kendileri de âdeta nur kesilmiş ve bütün sıkıntılarından kurtularak en büyük saadetlere ulaşmıştır:

$\begin{array}{ll}\text { “Len terânî” na're-i mestânedür gûş-ı dile } & \\ \text { Tûr-ı 'aşkam kûhsârumdan gelür bûy-ı şarâb } & \text { Âgâh (G. 23-5) } \\ \begin{array}{l}\text { Gönül nûr-ı tecellî ile 'Âşı Tûra dönmişdür } \\ \text { Fürûg-ı âfitâb-1 'âlem-ârâdan ferâgum var }\end{array} & \text { Âşık Çelebi (G. 83-6) } \\ \text { Biz bârika-i 'ışk ile kim nûr-siriştüz } & \\ \text { Rûşen-dil olursak ne 'aceb Tûr-siriştüz } & \text { Mezâkî (G. 182-1) } \\ \text { Tûr-ı dilde hüsnün envârı tecellî gösterip } & \\ \text { Yine ben dervişine dâg üstünü bâg eyledi } & \text { Usûlî (G. 135-3) }\end{array}$

Aşk ve muhabbet nurundan eser bulunmayan gönül ise ıssız ve kayalık bir çöle benzer, muhabbet Tûr'u olamaz. Böyle bir gönle sahip olan kimsenin tecelli ve onun neşesinden nasibi yoktur:

Her dilde bulınmaz eser-i nûr-ı mahabbet

Her sahra-yı sammâya dimem Tûr-ı mahabbet Nehcî (G. 121-1)

Zâhidi zühd ile sanma ki harâbâta gele

Okurum Mûsîyi kim Tûr-ı münâcata gele Nesîmî (G. 396-1)

Masiva tozlarından temizlenmiş bir gönle sahip âşık, Tûr Dă̆ı veya Eymen Vadisi’ni gezmeye ihtiyaç duymaz. Çünkü gönül aynası bu temiz hâliyle her an tecelliye açıtır ve onu algılar. Ayrıca bu tecelli ona hastır, Tûr'a ve Eymen Vadisi’ne ulaşandan çok daha başka ve özeldir:

Yeter âyîne-i sîne-güşâd tûtî-i tab‘a

Ne seyr-i kûh-ı Tûr ister ne geşt-i Vâdi-i Eymen Sâkıb Dede (G. 132-7)

Ol bârika kim bu dil-i pür-şûra tokındı

Ne vâdî-i Eymen ne ser-i Tûra tokındı Mezâkî (G. 407-1)

Bu tecelli öyle bir hâldedir ki değil kendisi, onun gönüldeki şevkini duymak bile Tûr'un bütün eczasını yakıp kül eder. Gönlün, taştan olduğu hâlde Tûr'un dayanamadığı o nura dayanabilmesi hayret verici bir durumdur. Bu durum, onun Tûr Dağı'ndan daha sağlam yaratılmış olduğunu gösterir:

Küll-i eczâsı anun kül ola od gibi hemîn

Dildeki şevk-ı tecellîyi eger Tûra disem

Zâtî ( G. 865-5) 
Tûr-ı Mûsâ döymedi envâr-ı hüsnün tâbına

Hey ne taşdan yüregüm var imiş Allâh'um benüm Âhî (G. 67-4)

Nice tâkat getirmiştir bu envâr-ı tecellâya

Meğer kim berk imiş yâ Rab gönüller Tûr-1 Mûsâ'dan Şeyhî (G. 130-3)

\subsubsection{Vücut}

Âşıkların maddi vücudu da tecelli nuru ile sarmalandığından dolayı Tûr Dă̆ı gibidir. Gönül, bu hâldeki vücutta Eymen Vadisi'ne benzer. Can ise bu vadide Allah tarafından bitirilip yetiştirilmiş iman ağacındaki aşk ateşini ve tecelli nurlarıyla dolu gönlü seyrederek kendinden geçen Hz. Musa gibidir:

Tûr gibi nûr-ı tecellî-i Rabb

Sardı bu cismin der ü dîvârına

Şeyh Gâlib (Trc. B. 1-40)

Bitürdün Eymen-i dilde dıraht-ı îmânı

Ki göre Mûsî-i cân 'ışk odından anda şihâb

Hamdullah Hamdî (G. 8-10)

Gönlümüz nûr-ı tecellî cismimizdir kûh-ı Tûr

Cânımız dîdâra karşı oldu Mûsî-vâr mest

Nesîmî (G. 22-29)

Âşı̆̆ın vücudu gerek zahir, gerekse bâtında tecelli veya onun arzusu ile çeşitli hâllere girer. Aşk ile saçları ağarmış vaziyette nura gark olmuş Tûr Dağı gibi görünür:

Pîr-i '1şk oldum depem ağardı ey Yahyâ benüm

Tûr-veş envâra gark itdi bahâristânumuz Yahyâ Bey (G. 165-7)

Hakk'ın cemâlini görme arzusuyla gönlü nur mahzeni kesilen âşığın gözleri ve sinesinde göz göz olmuş yaraları tecelli nurunu görmek için arşa açılmış pencerelerdir:

Şevk-i hüsnünle dili mahzen-i nûr eylemişüz

Dîdemüz revzene-i pertev-i Tûr eylemisüz Nâbî (G. 268-1)

Açuhdur 'arşa gönlümün evinden

Tecellî nûrı-y-ıçun bunca revzen $\quad$ Ahmedî (K. 63-35)

Onun 'sîne’si de Tûr-i 'Sînâ' gibidir. Aşk Musa'sı orada ikamet etmekte ve buradan tecelli şimşeklerini kendine çekmektedir. Âşığın vücudu bu yüzden yaralanıp parça parça olmuştur.

Rehîn-i tîğdır kûh-ı beden berk-ı tecellâdan

Kelîm-i aşk Tûr-ı sînede ber-câ mıdır bilmem Şeyh Gâlib (G. 207-6)

Tecelli ateşi âşıkların vücudunu Tûr Dağı gibi yakar ve onda Tûr Dağı gibi yaralar oluşturur. Bu yaralar öyle bir ateşle oluşmuştur ki, o ateşin bir parıltısı binlerce Tûr'u kül eder:

Hayretî kılsa tecellî pertev-i dîdâr-ı yâr

Tûr-ı Mûsâ gibi ânîde karara yana dâğ

Hayretî (G. 171-5)

Şu âteşden yanar dâg-ı derûnı ehl-i ‘ışkun kim

Kül eyler nârınun bir lem‘ası bin Tûr-ı Mûsâ'yı Nev’î (G. 537-3) 
Âşığın, Hakk’n cemâline duyduğu iştiyakla yanan gönlünden çıkarak duman gibi semaya yükselen ateş dolu her bir âhı Tûr'da tecelliye mazhar olan ağaca benzer ve onun hâlleri ile hâllenir. Bununla birlikte, o âh fidanları henüz Tûr'daki ağacın tohumu çimlenmeden, aşk ile serpilip ışıklar saçmıştır:
Ol serv-i gül-fürûş-ı tecellî-i cilveden
Her nahl-i âh bir şecer-i Tûrdur bana
Şeyh Gâlib (G. 1-2)
Dûd-ı âh-ı dil-i 'âşıkda ruhun yâdı ile
Şecer-i Tûr-ı tecellâdaki hâlet görünür
Nâ’ilî (G. 96-4)
Şu'le-bâr etmiş idi aşk nihâl-i âhım
Olmadın serzede tohm-ı şecer-i Tûr henüz
Nâ'ilî (G. 143-4)

\section{3. Çeşitli Hâller:}

\subsubsection{Tevazu, Niyaz}

Maddi büyüklük ve heybet kişiyi büyütmez. İnsan, tevazu ile büyür ve kıymet kazanır. Diğer dağlardan küçük olduğu hâlde Tûr, tevazu neticesinde erdiği tecelli ile yüce bir kıymete ulaşmıştır. Bu bakımdan görünüşe aldanmamak ve kimseye hor bakmamak gerekir:

Cesâmetle olaydı gayrdan rüchânı her şahsun

Akal-iken niçün a'zam olaydı her cibilden Tûr $\quad$ Edirneli Nazmî (G. 1552-4)

Kiçiye alçak dime kim kim bilür

Ola ulu kadr-ile niteki Tûr $\quad$ Edirneli Nazmî (G. 1261-2)

İnsan, su gibi temiz olmalı ve alçaklara akmalı; yani temiz bir kalp ile daima tevazu yolunu tutmalıdır. Âşıkların vücudu bu hâl ile yapılan niyaz sayesinde tecelli Tûr'u hâline gelmiştir:

Su gibi turı tur çâh-ı tenezzülde niyaz eyle

Vücûdı ‘âşık-ı sâdıklarun Tûr-ı tecellâdur

Yahyâ Bey (G. 134-4)

Âşık, gözleyip durduğu tecelliye kendini lâyı görmez. Bununla birlikte Allah'a niyazdan hiç bir zaman geri kalmaz. Niyaz onun Tûr'udur. O, bu sayede yükselip varılı sınırlarını aşarak Allah'’a yaklaştıkça yaklaşmıştır:

Şâyetse değilsek de tecellî-i cemâle

Vâdî-i tekellümde ser-efrâz-ı hitâbız

Şeyh Gâlib (G. 128-3)

Meskeni Tûr-ı niyâz u hemdemi hızr-ı Nebî

Menzil-i ednâ olan 'arş-1 'alâdur 'âşıka

Yahyâ Bey (G. 396-2)

\subsubsection{Fenâ, Mahviyet, Vahdet}

Tûr'un fenâ kavramı ile bağlantılı olarak zikredilmesi tecelli öncesi ve sonrası olmak üzere iki esasa dayanır. Her dağ tecelliye erişmeye kabiliyetli olmadığı gibi, ilahî muhabbetten uzak kalması münasebetiyle sadece bir toprak yığını olmaktan öteye geçemeyen insanlar da değildir. Buna ancak fenaya eren, yani benlik ve masiva emarelerinden arınmış aşığın gönlü ulaşabilir. Fenâ ile cilalanmış gönlün erdiği tecelli Tûr'da yoktur:

Degül her hâk-i tûde müsta‘id lem‘a-yı dîdâra 
Dil-i 'âşılk gibi ol berka bir Tûr-ı fenâ olmaz

Fenâdan öyle mi saykal alur Nehcî dil-i ‘âşı

Tecellîden ki vara berk-i istignâ düşe Tûra
Nehcî (G. 203-2)

Nehcî (G. 340-5)

Fenâya eren kimseler tecelliye mazhar olduklarında, onları tecelli nurundan ayırt etmek neredeyse imkânsız hâle gelir. Bunlar bu hâl neticesinde ortaya çıkan mahviyet ve sarhoşluk sebebi ile artık kendilerinden bir eser bulamazlar. Böylece erdikleri vahdet hâli ile maddi ve manevi vücutları nur, bulundukları yer Tûr kesilir. Her neye baksalar tecellileri müşahede ederler. Kendilerini bu vahdet hâlinin coşkunluğu ile artık Hz. Musa, Mukaddes Eymen Vadisi, Tûr, Tûr'daki ateş ve tecelli nuru olarak görürler:

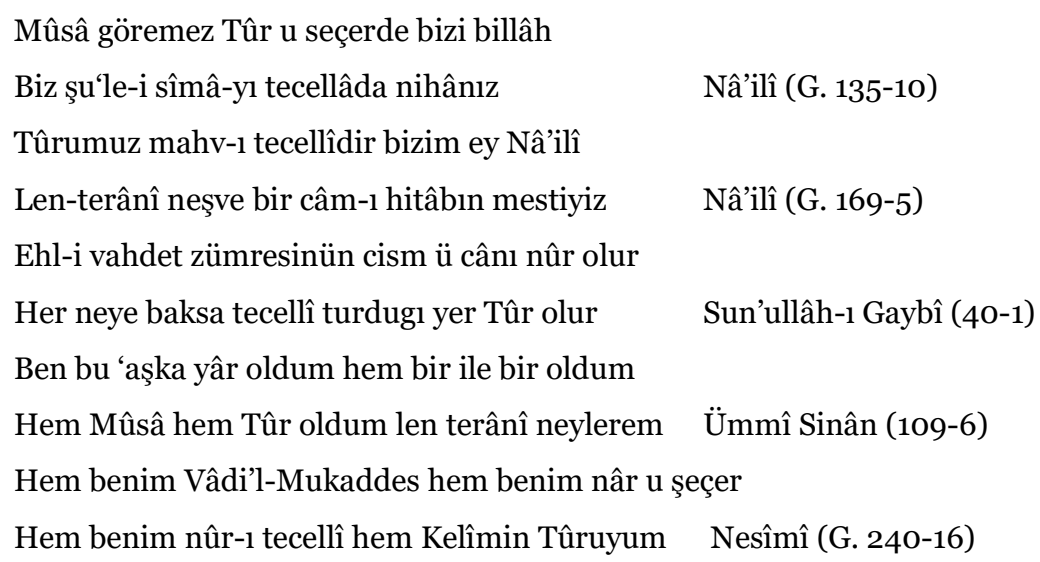

\section{3•3. Vecd, Cezbe, Şevk, İstiğrak}

Manevi coşkunluk ifade eden bu hâller kendinden geçme ve sarsılma gibi şekillerde kendini gösterir. Tecellinin parıltısı ile Tûr'un sarsılıp parçalanması bu hâllerin bir yansıması olarak görülür.

Hakk'ın tecellisi karşısında hiçbir şeyde dayanacak güç yoktur. Onun bir parıltısı binlerce Tûr ve Eymen Vadisi'ni yakar, can ve gönülleri bedenden ayırır. Bütün seçkin ruhlar, Hz. Musa gibi onun en ufak bir cezbesinin pervanesi olur. Onların vücutları da vecd ile Tûr gibi sarsılıp raks eder:

Hüsnünün bir pertevi çok cân u dil pertâb ider

$\begin{array}{ll}\text { Bir tecellî âteşi bin Tûr u bin Eymen yakar } & \text { Hayretî (G. 64-4) } \\ \text { Kem-cezbe-i tecellî-i hüsnün Kelîm-vâr } & \\ \text { Ervâh-ı kudsu şu'le-gedâyân-ı Tûr eder } & \text { Nâ’ilî (G. 114-4) } \\ \begin{array}{l}\text { Eylese bir kez tecellî şübhesiz } \\ \text { Raksa gelür Tûr-ı ten devrân ider }\end{array} & \text { Mehmed Sıdkî (89-2) }\end{array}$

Bu hâldeki âşık, şevk deryasına gark olmuştur ve bu istiğrak vesilesi ile aşkın uzaktan âdeta ateş gibi yakıcı ve elem verici görünen tezahürleri artık ona ferahlık ve mutluluk kaynağıdır. Bir diğer ifadeyle, önceden celal ateşi zannedilen şeylerin aslında cemal nuru, bu yoldaki zorlukların aslında birer rahmet olduğu ortaya çıkmış olur:

Şol kadar müstağrak-ı deryâ-yi eşvâkam bugün

Nûrdan fark etmezem Tûr-ı mahabbet nârını Hayâlî (G. 582-2)

Sîne pür-şu'le-i şevk olsa dil-i Mûsî-vâr 


\section{Sonuç}

Klasik Türk şiirinde Tûr-i Sînâ tasavvufî açıdan tecelli kavramı ekseninde ele alınmış ve bu eksende genel olarak insan-ı kâmil ve Allah âşıklarının anlatımında temel bir benzetme ve kıyaslama unsuru olarak değerlendirilmiştir. İlgili anlatımlar başlıca şu düşünceleri yansıtmaktadır:

1. Bütün kâinat Hakk’’n tecellileri ile doludur. Bunu anlayabilen insan için her yer Tûr Dağı'dır.

2. En has tecellilere seçkin kullar yani peygamberler, insan-ı kâmiller ve Allah âşıkları erişmiştir.

3. Tûr gibi tecelliye mazhar olabilmek için, Hakk’’ talep ile nefsin hayvani yönlerini ve benlik davasını ortadan kaldırıp gönlü masivadan temizlemek suretiyle aşk âlemine dalmak gerekir.

4. Tecelliye mazhar olan kimseler, gerek bâtın gerekse zahiri tecelli nurlarına mazhar olmakla Tûr Dağı'na benzerler.

5. Tecelliye mazhar olan kimseler Tûr ve buradaki Hz. Musa'ya benzer hâller yaşarlar. Bu hâllerin en belirginleri fena, vahdet, vecd, şevk ve istiğraktır.

Bu ve benzeri düşüncelerin sergilenmesindeki başlıca gaye, dinî-tasavvufi bakış açısına dayalı olarak insanları nefse bakan yönüyle aşağılık olan dünya hırsından ve başta benlik davası olmak üzere çirkin vasıflardan soğutarak, ruh ve gönül âlemine ve bu âlemin güzelliklerine yöneltmek suretiyle Allah'a yaklaşmalarına vesile olmaktır. Klasik Türk şiirinde Tûr-i Sînâ, bu gaye yolunda önemli bir timsal olarak arzıendam etmektedir.

\section{Kaynakça}

Abdulkerim Ceylî (2018.03.03). İnsan-ı Kâmil. Çev. Abdulkadir Akçiçek. https://archive.org/details/Sir-e-kitap-insan-iKamil-abdulkerimCeyli-

Abdulkerim Kuşeyrî (2003). Kuşeyrî Risâlesi. hzl. Süleyman Uludağ. İstanbul: Dergâh Yay.

Âgâh Dîvânı. hzl. Şerife Akpınar (2017). http://ekitap.kulturturizm.gov.tr/TR,195642/agahdivani.html [19.04.2018].

Âhî Dîvânı. hzl. Mustafa S. Kaçalin. http://ekitap.kulturturizm.gov.tr/TR,78356/ahi-divani.html (12.02.2018).

Ahmedî Dîvânı. hzl. Yaşar Akdoğan. http://ekitap.kulturturizm.gov.tr/TR,78357/ahmedi-divani.html (12.02.2018).

Ahmedî, Mevlid (Ahmedî Dîvânı içinde). hzl. Yaşar Akdoğan. http://ekitap.kulturturizm.gov.tr/TR,78357/ahmedi-divani.html (12.02.2018).

Âşık Çelebi Dîvânı. hzl. Filiz Kılıç (2017). http://ekitap.kulturturizm.gov.tr/TR,195827/asik-celebidivani.html [08.04.2018].

Avnî Dîvânı. hzl. Muhammed Nur Doğan. http://ekitap.kulturturizm.gov.tr/TR,78360/avni-fatihdivani.html (12.02.2018).

Azmizâde Hâletî Dîvân. hzl. Bayram Ali Kaya (2017). http://ekitap.kulturturizm.gov.tr/TR,196456/azmizade-haleti-divani.html [11.02.2018].

Bâkî Dîvânı. hzl.: Sabahattin Küçük (1994). Ankara: TDK Yay. 
Beyânî Dîvânı. hzl. Fatih Başpınar. http://ekitap.kulturturizm.gov.tr/TR,78363/beyani-divani.html (12.02.2018).

Buhârî (1989). Sahîh-i Buhârî ve Tercemesi. mütercim: Mehmed Sofuoğlu. C. XIV. İstanbul: Ötüken Yay.

Edirneli Nazmî Dîvânı. hzl. Sibel Üst (2018). http://ekitap.kulturturizm.gov.tr/TR,78367/edirnelinazmi-divani.html [12.02.2018].

El-Aclûnî, İsmail b. Muhammed (2009). Keş̧ü'l Hafâ ve Müzîlü'l-İlbâs C. II. Beyrut: Dârü'l-Kütübi'l‘ilmiyye.

Hamdullah Hamdî Dîvânı. hzl. Ali Özyıldırım. http://ekitap.kulturturizm.gov.tr/TR,78375/hamdullah-hamdi-divani.html (12.02.2018).

Harman, Ömer Faruk (1993). "Dağ". Türkiye Diyanet Vakfi İslam Ansiklopedisi. C. VIII. İstanbul: Türkiye Diyanet Vakfi Yay. 400-401.

Hayâlî Dîvânı. hzl. Ali Nihat Tarlan (1992). Ankara: Akçă̆ Yay

Hayretî Dîvânı. hzl. Mehmed Çavuşoğlu, M. Ali Tanyeri. http://groups.yahoo.com/neo/groups/metinbankasi/files, Dec. 31. 2004 versiyonu.

İmam Gazâlî (1994). Mişkatü'l-Envâr. çev. Süleyman Ateş. İstanbul: Bedir Yay.

İsmail Hakkı Bursevî, Kitâbü’l-Envâr. İ.B.B. Atatürk Kitaplı̆̆ Sayısal Arşiv ve e-Kaynaklar. No. 297.7. http://katalog.ibb.gov.tr/kutuphane2/yazmalar/BEL_Yz_Ko589.pdf (03.03.2018).

Kâdı Beydâvî (2011). Muhtasar Beydâvî Tefsiri (Envâru't-Tenzîl ve Esrârü't-Te'vîl). C. 4. Tercüme ve Dipnotlar: Şadi Eren. İstanbul: Selsebil Yay.

Kâtib-zâde Sâkıb Dîvânı. hzl. Mehmet Kirbiyık (2017). http://ekitap.kulturturizm.gov.tr/TR,199763/katib-zade-sakib-divani.html [08.04.2018].

Kur'an-ı Kerim Meâli (2011). hzl.: Halil Altuntaş- Muzaffer Şahin. Ankara: Diyanet İşleri Başkanlığı Yay.

Mehmed Sıdkî Dîvânı. hzl. Abdullah Eren (2017). http://ekitap.kulturturizm.gov.tr/TR,195956/mehmed-sidki-divani.html [11.02.2018].

Mermer, Ahmet (1991). Mezâkî Hayatı, Edebî Kişiliği ve Dîvâninın Tenkitli Metni. Ankara: Atatürk Kültür Merkezi Yay.

Mevlânâ (2017). Mesnevî -Tam Metin-. Türkçesi: Adnan Karaismailoğlu. Ankara: Akçağ Yay.

Nẩili Dîvânı. hzl. Haluk İpekten (1990). Ankara: Akçağ Yay.

Nâbî Dîvânı. hzl. Ali Fuat Bilkan (1997). İstanbul: MEB Yay.

Nakşî Dîvânı. hzl. Emrah Ayhan. http://groups.yahoo.com/ neo/groups/metinbankasi/files, Jan. 4. 2005 versiyonu.

Nehcî Dîvânı. hzl. Üzeyir Aslan (2017). http://ekitap.kulturturizm.gov.tr/TR,194366/nehci-divani.html [12.02.2018].

Nesîmî Dîvânı. hzl. Hüseyin Ayan (1990). Ankara: Akçă̆ Yay.

Nevî, Divan. hzl. Mertol Tulum, Ali Tanyeri (1977). İstanbul: İstanbul Üniversitesi Fen Edebiyat Fakültesi Yay.

Sâkıb Dede Dîvânı. hzl. Ahmet Arı. http://ekitap.kulturturizm.gov.tr/TR,78398/sakib-dededivani.html (12.02.2018).

Sinanoğlu, Mustafa (2009). "Sînâ" Türkiye Diyanet Vakf İslam Ansiklopedisi. C. XXXIV. İstanbul: Türkiye Diyanet Vakfi Yay. 221-222.

Sun'ullâh-ı Gaybî Dîvânı. hzl. Bilal Kemikli (2000). İstanbul: M.E.B. Yay.

Süheylî Dîvânı. hzl. M. Esat Harmancı (2017). http://ekitap.kulturturizm.gov.tr/TR,194364/suheylidivani.html [12.02.2018]. 
Şeyh Gâlib Dîvânı. hzl. Muhsin Kalkışım (1994). Ankara: Akçağ Yay.

Şeyhî Divanı. hzl.: Mustafa İsen, Cemâl Kurnaz (1990). Ankara: Akçă̆ Yay.

Şeyhülislam Yahyâ Dîvânı. hzl. Hasan Kavruk. http://ekitap.kulturturizm.gov.tr/TR,78405/seyhulislam-yahya-divani.html (11.02.2018).

Usûlî Divanı. hzl. Mustafa İsen (1990). Ankara: Akçağ Yay.

Ümmî Sinân Dîvânı. hzl. A. Azmi Bilgin (2017). http://ekitap.kulturturizm.gov.tr/TR,195646/ummisinan-divani.html [08.04.2018].

Vusûlî Dîvânı. hzl. Hakan Taş (2010). http://ekitap.kulturturizm.gov.tr/TR,78409/vusuli-divani.html [12.02.2018].

Yahyâ Bey Dîvânı. hzl. Mehmed Çavuşoğlu (1977), İstanbul: İstanbul Üniversitesi Edebiyat Fakültesi Yay.

Zâtî Dîvânı. hzl. Ali Nihad Tarlan (1970). C. II. İstanbul: İstanbul Üniversitesi Fen Edebiyat Fakültesi Yay. 